multifocal ERG ${ }^{8}$ recorded a- and b-waves and OPs, and demonstrated delayed recovery of OPs in case 2, which may imply inner retinal layer involvement in MEWDS. Similar findings have been reported in central serous chorioretinopathy. ${ }^{14}$

I Jampol LM, Sieving PA, Pugh D, Fishman GA, Gilbert H Multiple evanescent white dot syndrome: I. Clinical Multiple evanescent white dot syndrom

2 Sieving PA, Fishman GA, Jampol LM, Pugh D. Multiple evanescent white dot syndrome: II. Electrophysiology of the evanescent white dot syndrome: II. Electrophysiology of the

3 Dodwell DG, Jampol LM, Rosenberg M, Berman A, Zaret CR. Optic nerve involvement associated with the multiple evanescent white-dot syndrome. Ophthalmology 1990; 97: 862-8.

4 Hamed LM, Glaser JS, Schatz NJ, Gass DM. Acute idiopathic blind spot enlargement without optic disc edema. Arch Ophthalmol 1988; 106: 1030-1.

5 Hamed LM, Glaser JS, Gass DM, Schatz NJ. Protracted enlargement of the blind spot in multiple evanescent white dot syndrome. Arch Ophthalmol 1989; 107: 194-8.
6 Aarberg TM. Multiple evanescent white dot syndrome. Arch Ophthalmol 1988; 106: 1162-3.

7 Kimmel AS, Folk JC, Thompson HS, Strand LS. The multiple evanescent white dot syndrome with acute blind spot enlargement. Am $\mathcal{F}$ Ophthalmol 1989; 107: 425-6.

8 Fletcher WA, Imes RK, Goodman D, Hoyt WF. Acute idiopathic blind spot enlargement. A big blind spot syndrome without optic disc edema. Arch Ophthalmol 1988; 106: 44-9.

9 Horiguchi M, Miyake Y, Yagasaki K, Ichikawa K. Temporal aspects of the electroretinogram in cone-rod dystrophy. Doc Ophthalmol 1985; 60: 219-27.

10 Miyake Y. Studies of local macular ERG. Acta Soc Ophthalmol fpn 1988; 92: 1419-49.

11 Miyake Y, Shiroyama N, Ota I, Horiguchi M. Oscillatory potentials in electroretinogram of the human macular region. Invest Ophthalmol Vis Sci 1988; 29: 1613-35.

12 Miyake Y, Shiroyama N, Horiguchi M, Ota I. Asymmetry of focal ERG in human macular region. Invest Ophthalmol Vis Sci 1989; 30: 1743-9.

13 Sigh K, Frank MP, Shults WT, Watzke RC. Acute idiopathic blind spot enlargement. A spectrum of disease. Ophthalmology 1991; 98: 497-502.

14 Miyake Y, Shiroyama N, Ota I, Horiguchi M. Local macular electroretinographic responses in idiopathic central serous chorioretinopathy. Am $\mathcal{f}$ Ophthalmol 1988; 106: 546-550.

\title{
Contralateral active ocular toxoplasmosis in Fuchs' heterochromic cyclitis
}

\author{
E La Hey, G S Baarsma
}

Department of

Ophthaimo-Immunology,

The Netherlands

Ophthalmic Research

Institute, Amsterdam

E La Hey

The Eye Hospital, Rotterdam, The

Netherlands

G S Baarsma

Correspondence to:

Dr Ellen La Hey, Departmen

of Ophthalmo-Immunology,

The Netherlands Ophthalmic

Research Institute,

Amsterdam, The

Netherlands.

Accepted for publication

19 February 1993
Many authors have published papers on the assumed association between Fuchs' heterochromic cyclitis and ocular toxoplasmosis. ${ }^{1-8}$ Most studies reported on the presence of chorioretinal scars which were clinically consistent with a previous intraocular toxoplasmosis. In the majority of cases these toxoplasmosis-like lesions were present in the cyclitic eye. Only a few patients with Fuchs' heterochromic cyclitis and active Toxoplasma retinochoroiditis have been described..$^{1-378}$ Until now, this clinical picture of toxoplasmosis was confirmed by aqueous humour analysis in two cases only. ${ }^{2}$ In a recent study we found a significantly higher incidence of toxoplasmosis-like chorioretinal scars in patients with Fuchs' heterochromic cyclitis than in a control group of patients with an HLA-B27positive anterior uveitis. ${ }^{6}$ Although we found this positive clinical association between Fuchs' heterochromic cyclitis and toxoplasmosis-like scars, it could not be substantiated by serological tests for toxoplasmosis (immunofluorescence or ELISA) or by a test for cellular immunity to Toxoplasma antigen. Analysis of aqueous humour samples for Toxoplasma antibodies also yielded negative results. One must keep in mind, however, that no active chorioretinal lesions were present in the patients with Fuchs' heterochromic cyclitis at the time of blood sampling, nor at the time when the aqueous humour samples were obtained (during cataract surgery) ${ }^{6}$

Here, we report on a patient with unilateral Fuchs' heterochromic cyclitis who developed an active toxoplasmosis of the contralateral eye, which could be proved by aqueous humour analysis.

\section{Case report}

A 28-year-old patient consulted our ophthalmology department with complaints of a diminished visual acuity of the left eye (6/6 on the right, hand movements (HM) on the left). Ophthalmic examination disclosed small white keratic precipitates scattered on the endothelium, $1+$ flare in the aqueous, diffuse iris stromal atrophy, no posterior synechiae, and evident heterochromia. A dense subcapsular cataract was present. Tests to exclude other causes of uveitis were all within normal range. Based on the clinical picture our diagnosis was Fuchs' heterochromic cyclitis. The right eye showed no anterior segment abnormalities, but fundus examination disclosed small pigmented chorioretinal scars nasally. During the cataract extraction we obtained aqueous humour of the left eye after informed consent. No Toxoplasma antibodies could be detected, even in undiluted aqueous humour. The Toxoplasma antibody titre in a paired serum sample was 1:32. No fundus lesions were seen after removal of the cataract. Two years later, this patient returned with a diminished visual acuity of the right eye $(6 / 12$ on the right, 20/24 on the left). The left eye still showed the typical clinical features of Fuchs' heterochromic cyclitis, as described above. The right eye showed mutton fat keratic precipitates, 
Table 1 Results of investigation of intraocular production of antibodies against various micro-organisms ${ }^{910}$

\begin{tabular}{llllll}
\hline & $\begin{array}{l}\text { Toxoplasma } \\
\text { gondii }\end{array}$ & HSV & $C M V$ & $E B V$ & VZV \\
\hline Serum titre & $1: 16$ & $<1: 16$ & $1: 16$ & $1: 256$ & $1: 256$ \\
Aqueous titre & $1: 4$ & 0 & 0 & $1: 2$ & $1: 4$ \\
Coefficient & 22 & 0 & 0 & $<1$ & $1: 4$ \\
\hline
\end{tabular}

$\mathrm{HSV}=$ herpes simplex virus, $\mathrm{CMV}=$ cytomagalovirus, $\mathrm{EBV}=\mathrm{Epstein}-\mathrm{Barr}$ viurs, $\mathrm{VZV}=$ varicella zoster virus

$1+$ cells in the aqueous, and many vitreous opacities. No iris abnormalities were seen. The fundus was difficult to examine owing to many vitreous opacities; disc oedema, periphlebitis, and an active focal retinochoroidal lesion could be discerned. A diagnostic anterior chamber paracentesis was performed. Using an immunofluorescence test, local intraocular antibody production against various micro-organisms was investigated, as described earlier..$^{910}$ A positive Goldmann-Witmer coefficient of 22 ( $\geq 3$ is considered positive ${ }^{10}$ ) was found for Toxoplasma gondii, indicating an active intraocular production of Toxoplasma antibodies (Table 1)..$^{10}$ No intraocular production of antibodies against herpes simplex virus (HSV), cytomegalovirus (CMV), Epstein-Barr virus (EBV), or varicella zoster virus (VZV) could be detected. Based on the results of this aqueous humour analysis, a diagnosis of active ocular toxoplasmosis was made and therapy with clindamycin and sulphadiazine was started. Within several weeks the vitreous cleared; a retinochoroidal lesion typical of toxoplasmosis appeared in satellite formation next to old pigmented scars (Figure 1).

\section{Comment}

Until now, only one study reported two patients with Fuchs' heterochromic cyclitis and active Toxoplasma retinochoroiditis, in whom the clinical diagnosis of toxoplasmosis was confirmed by aqueous humour analysis. ${ }^{2}$ We recently described a patient with a definite congenital bilateral toxoplasmosis who developed a unilateral Fuchs' heterochromic cyclitis. ${ }^{4}$ The patient described in the current report had no clinical characteristics of toxoplasmosis in his eye with Fuchs' heterochromic cyclitis, but developed an active toxoplasmosis in the opposite eye, which could be proved by aqueous humour analysis. These few cases support the hypothesis that Fuchs' heterochromic cyclitis may be secondary to congenital toxoplasmosis.

Fuchs' heterochromic cyclitis, although considered as a separate nosological entity, has also been described in association with other (ocular) diseases; retinitis pigmentosa, ${ }^{11-13}$ ocular trauma, ${ }^{14}$ the subclavian steal syndrome, ${ }^{15}$ hemifacial atrophy, ${ }^{16}$ and Horner's syndrome. ${ }^{17}$ In a recent study on the association between Fuch's heterochromic cyclitis and toxoplasmosis several patients lacked the keratic precipitates typical of Fuchs' heterochromic cyclitis. ${ }^{3}$ On the other hand, patients with ocular toxoplasmosis sometimes have keratic precipitates characteristic of Fuchs' heterochromic cyclitis. Occasionally also pigmented keratic precipitates

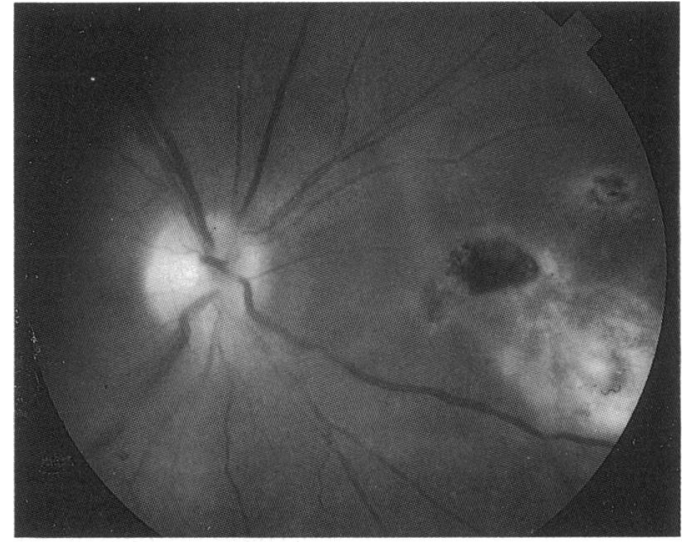

Figure 1 Fundus photograph of the right eye 3 weeks after the therapy was started. A fresh retinochoroidal lesion typical of toxoplasmosis appeared in satellite formation next to old pigmented scars.

are observed in patients with a typical clinical picture of Fuchs' heterochromic cyclitis. ${ }^{18}$ It is often difficult to make the diagnosis Fuchs' heterochromic cyclitis, since no minimal diagnostic criteria have been established internationally ${ }^{19}$ : in fact, a spectrum of signs may be seen in patients with this disorder. ${ }^{1819}$ It is therefore conceivable that Fuchs' heterochromic cyclitis may be a secondary phenomenon with a spectrum of clinical features and different causes, including congenital toxoplasmosis.

1 De Abreu ML, Belfort R, Hirata PS. Fuchs' heterochromic cyclitis and ocular toxoplasmosis. Am $\mathcal{F}$ Ophthalmol 1982 93: 739-44.

2 Saraux H, Laroche L, Le Hoang P. Secondary Fuchs's heterochromic cyclitis: a new approach to an old disease. Ophthalmologica 1985; 190: 193-8.

3 Schwab JR. The epidemiologic association of Fuchs' heterochromic iridocyclitis and ocular toxoplasmosis. Am $\mathscr{J}$

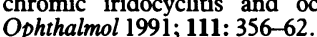

4 Arffa RC, Schlaegel TF. Chorioretinal scars in Fuchs' heterochromic iridocyclitis. Arch Ophthalmol 1984; 102: 1153-5.

5 La Hey E, Rothova A. Fuchs' heterochromic cyclitis in congenital ocular toxoplasmosis. Brf Ophthalmol 1991; 75 372-3.

6 La Hey E, Rothova A, Baarsma GS, de Vries J, van Knapen F, Kijlstra A. Fuchs' heterochromic iridocyclitis is not associated with ocular toxoplasmosis. Arch Ophthalmol 1992 110: 806-11.

7 Pezzi PP, Niutta A, Abdulaziz M, Paroli MP. Fuchs' heterochromic iridocyclitis and toxoplasmic retinochoroiditis. In f Ophthalmol 1987; 1/2: 97-101

8 Silva HF, Orefice F, Pinheiro SRA. Fuchs' heterochromic cyclitis: clinical study of 132 cases. In: Belfort R, Petrilli AMN, Nussenblatt R, eds. World uveitis symposium. Sao AMN, Nussenblatt R, eds. World uveitis sympo

9 Kijlstra A, Luyendijk L, Baarsma GS, Rothova A, Schweitzer CM, Timmerman Z, et al. Aqueous humor analysis as a diagnostic tool in toxoplasma uveitis. Int Ophthalmol 1989; 13: $383-6$.

$10 \mathrm{Kijlstra}$ A. The value of laboratory testing in uveitis. Eye 1990 4: $732-6$

11 Vourre I, Saari M, Tilikainen, Rasanen O. Fuchs' heterochromic cyclitis associated with retinitis pigmentosa: family study. Can $\mathcal{F}$ Ophthalmol $1979 ; 14: 10-6$.

12 Francois J, Mastilovic B. L'heterochromie de Fuchs associee aux heredo-degenerescences chorioretiennes. Ann Oculist 1961; 94: 385-96.

13 Winkler A. Retinitis pigmentosa sine pigmento auf dem einen und retinitis pigmentosa mit heterochromie-iridocylitis auf dem anderen auge. Klin Monatsbl Augenheilkd 1940; 105. $594-600$.

14 Vadot E. Cyclite heterochromique de Fuchs post-traumatique. Bull Soc Ophtalmol Fr 1981; 81: 665-7

15 Donoso LA, Eiferman RA, Magargal LE. Fuchs' heterochromic cyclitis associated with subclavian steal syndrome. Ann Ophthalmol 1981; 13: 1153-5.

16 Sugar HS, Banks TL. Fuchs' heterochromic cyclitis associated with facial hemiatrophy (sklerodermie en coup de sabre). Am $\mathcal{F}$ Ophthalmol 1964; 57: 627-32.

17 Regenbogen LS, Naveh-Floman N. Glaucoma in Fuchs' heterochromic cyclitis associated with congenital Horner's syndrome. Br f Ophthalmol 1987; 71: 844-9.

18 Jones NP. Fuchs' heterochromic uveitis: a reappraisal of the clinical spectrum. Eye 1991; 5: 649-61.

19 La Hey E, Baarsma GS, de Vries J, Kijlstra A. Clinical analysis of Fuchs' heterochromic cyclitis. Doc Ophthalmol 1991; 78: 225-35. 